\title{
Iránytű emlékbe, tudományos szövegekben utazóknak
}

\section{A fingerpost for journeys in scientific texts}

\author{
MAROSI LAJOS
}

Tizenöt évnyi (olvasó)szerkesztői munkám tapasztalatainak összegzésére nem elég néhány oldal, már csak azért sem, mert a Területi Statisztikánál, az Élet és Tudománynál, valamint a Tér és Társadalomnál gyüjtött benyomásaim ${ }^{1}$ igen sokszínűek (bár a tónusok inkább sötétbe hajlanak). Néha azonban a rövid útmutatásra még tovább emlékszik az ember. Ahogy én is. Például a Központi Statisztikai Hivatalban, ahová eredetileg (1995-ben) elemzőnek szegődtem, osztályvezetőm, Friss Péter egyetlen támpontot adott: ügyeljek, hogy minden mondatban legyen világos, ki az alany. Magától értetődőnek tartottam ezt a föszabályt, de nem sértődtem meg, csak furcsállottam hangsúlyozását. Azután - külön figyelve rá - be kellett látnom, hogy az alany egyértelműségét nem is olyan könnyü összeegyeztetni a szóismétlések elkerülésével és az olvasmányos stílussal. Két évvel később az újraindított Területi Statisztika folyóirat szerkesztője lettem, és a szövegek gondozása is a feladataim közé tartozott. Főszerkesztőm, Kovács Tibor egyetlen támpontot adott: csak a legszükségesebb mértékben módosítsak a kéziratokon, el ne vesszen a szerzők egyéni stílusa. Ezt a főszabályt is magától értetődőnek tartottam, és csak menet közben döbbentem rá, mennyire nehéz betartani: annyi a javítanivaló, s oly kevés az egyéni stílus. ${ }^{2}$

Most eljött az idő, hogy én adjak - nem annyira tömör, de hasonlóan magától értetődőnek tűnő - útmutatást azoknak, akik tudományos szövegeket írnak, bírálnak vagy javítanak. Elsősorban a Tér és Társadalom szerzőinek, lektorainak és itteni szerkesztő barátaimnak. Írtam ilyesmit a Területi Statisztikába is, ${ }^{3}$ szerény haszonnal...

\section{A cikkek stílusa}

A kíváncsiság az ember legősibb és legszebb tulajdonságai közé tartozik. (A kíváncsiskodást nem számítva ide.) A kisded fáradhatatlanul ismerkedik a környezetével: a színes, a fényes, a hangot adó, a mozgó dolgokkal. Az összetett valamiket szétszedi, tetejüket lecsavarja. A zárt ajtókat kinyitja, a madarak röp-

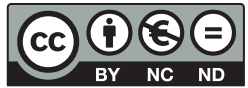


tét követi a tekintetével. ${ }^{4} \mathrm{~A}$ felnőtt kíváncsiságának (kortalanul) legkifinomultabb megnyilvánulása a tudományos kutatómunka. Az ilyen ember nem nőtte ki az állandó kérdezést, olthatatlan vágyat érez a világ jelenségeinek megértésére, az összetettet szétszedi, és az elemeket szintetizálja. (Önnön kíváncsiságáról mint hajtóerőről beszélt a vele készített interjúban ${ }^{5}$ Enyedi György akadémikus.) Az olvasó is kíváncsi. Ha publicisztikát olvas, ha szépirodalmat, ha kutatási beszámolót. Mindhármat úgy kell megírni, hogy az olvasónak legyen kedve elolvasni a következő mondatot, meg az utána jövőt is. A szakíró - akár szerény, akár lehengerlö -, ha unalmas tanulmányt hoz össze, árt tudományának és saját tekintélyének.

Hogyan lehet a kutató elme által talált megoldásokat kimerítően előadni? ó, hát annak gazdag eszköztára van! Elöször a görcsös igyekezet, hogy a szöveg eltérjen a köznyelvtől. Többszörösen összetett mondatok, oda nem illő kötőszavak alkalmazása. Az igék helyettesítése terpeszkedő kifejezésekkel ${ }^{6}$ (,,megfogalmazást nyer”, „kiszabályozásra kerül”). Idegen szavak burjánzása, angoloké germanizmusba, németeké anglicizmusba merítve. Másodszor az olvasóközönség ismeretszintjének figyelmen kívül hagyása, képességeinek túlbecsülése vagy lekicsinylése. A szöveg nagyobb részének kiemelése vastag betűkkel, a gyengébbek kedvéért. Harmadszor a cikk megtűzdelése messzire vezető kitérőkkel, felejthető részletekkel, ismert és ismeretlen tekintélyekre való hivatkozásokkal. Én meg azt várom el, hogy a tudományos szöveg is legyen természetes, ne legyen benne keresettség, dagályosság, eredetieskedő kifejezés (vö. Szathmári 2004). Persze tisztában vagyok vele, hogy a publicisztikai, a szépirodalmi, az ismeretterjesztő és a tudományos stílus sok megkülönböztető jegyet visel (1. táblázat), de mindegyik a köznyelven alapul - esetünkben a magyaron.

A tudományos cikkekről a táblázatban mondottakhoz csak néhány észrevételt teszek.

- Minél precízebb egy cím, annál hosszabb. Pontoskodót, hosszút írni könnyebb, mint lényegkiemelőt és találót. A tanulmány főcímét kísérheti egy második cím is, s ezek között eloszthatók a szerepek, például így: a tömör föcím felkelti a figyelmet, megmozgatja a fantáziát, a kiegészítő cím pedig lehoz a földre, egyértelművé teszi az írás tárgyát.? (A szerző tévedhet, ha a témája iránti érdeklődést eleve adottnak véli.) Amit előzetesen címnek szántunk, az inkább munkacím, s a cikk befejezésekor esetleg meg kell változtatni. Gondolni kell arra is, hogyan hangzik a választott cím idegen nyelven. Ami magyarul frappáns, az lesz-e vajon angolul is? Aztán ott van az alcímrendszer (ott van?), amely megérne egy külön fejezetet. Ehelyett most annyit, hogy a szerző számára hasznos önellenőrzés, ha alcímeit - azok minden szintjét - kiírja, és egymáshoz viszonyítva megszemléli. Ebben a tükörben megláthatja gondolatmenetének ívét, logikáját, a részek arányosságát (vagy - még kimondani is szörnyü - azok hiányát). Iskolás alcímeket ne adjunk (Bevezetés, Összefoglalás), még doktori iskolásakat se (Alapvetés, Konklú- 


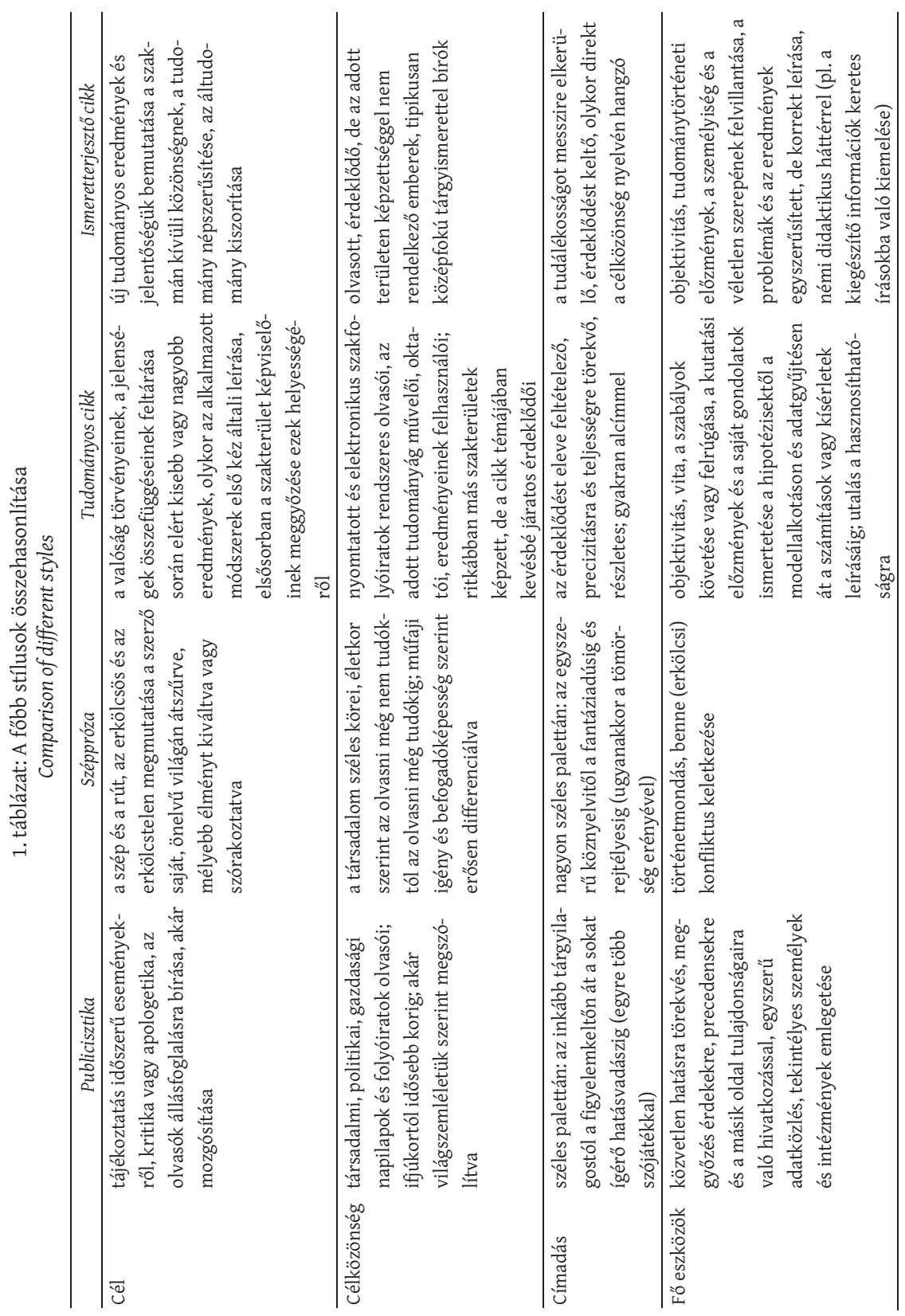




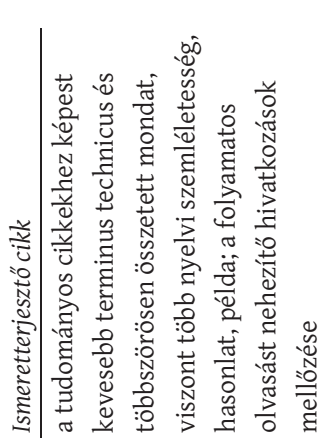

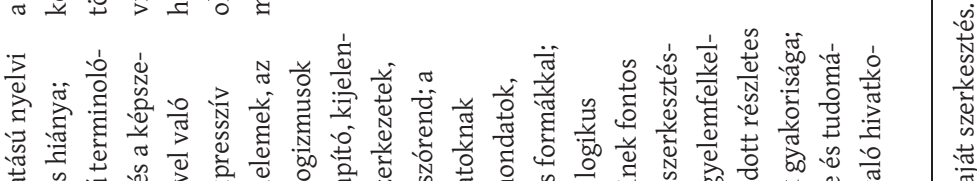

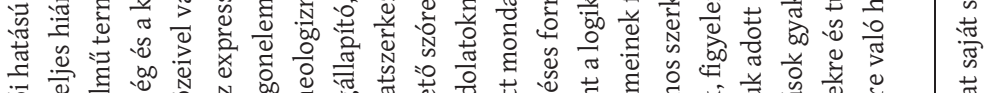

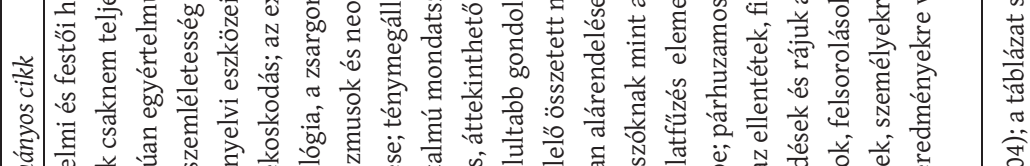

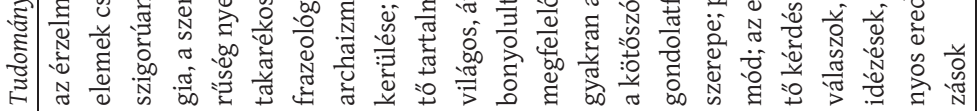

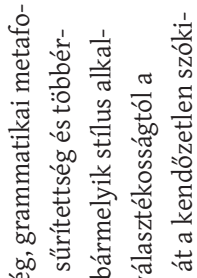

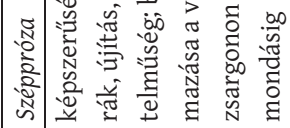

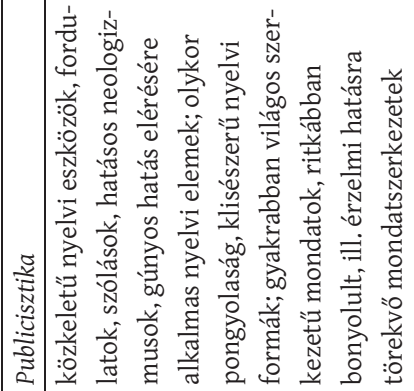

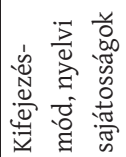


zió)! Egy tudományos igényü munka ezeknél eredetibb, testre szabottabb alcímeket érdemel. De az összefoglalásnak nem is a megnevezését lehet leginkább elrontani, hanem a tartalmát. Tipikus hiba, ha a szerző pusztán megismétli a dolgozat fontosabb mondatait. Ez húszoldalas tanulmányok esetén felesleges, százoldalas írásoknál indokolt lehet. $\mathrm{Az}$ meg egyenesen bosszantó, ha a szerző szintézis, új gondolat helyett a befejezést még a szakirodalmi hivatkozásokkal is teletűzdeli.

- A KKV-t, a PPP-t és az önhikit - hasonló társaikkal együtt - nem számítom a szakmai terminológiához. Ezek a belterjes zsargon mintapéldányai. A valódi szakszavakkal is lehet azonban probléma. Főleg akkor, ha csak állandó szótárhasználattal olvasható az egyébként magyar szöveg. Az alábbi szószedet egy korábbi írásomból való (Marosi 2011, 578.), de kénytelen vagyok ide átemelni. „Semmi bajom a következő szavakkal: ambiciózus, aspektus, determinizmus, gentleman, geográfia, globálisan, hidrográfia, historiográfia, interdiszciplináris, interpretáció, klimatikus, kognitív, koloniális, kommunikáció, konstruáltság, kontextus, koreografált, kozmopolitizmus, kvantitatív, legitimitás, lokális, materiális, mobilizációs, morfológia, naturalista, navigáció, ontológiai, partikuláris, pluralizmus, posztkolonialista, posztstrukturalista, potenciális, prototípus, provinciális, publikál, puritanizmus, recenzió, rekonstruálás, reprezentációs, retorika, revizionista, standardizáló, szubnacionális, transzcendensen, uniformizálás, univerzálisan, univerzalitás - semmi bajom velük egyenként. Csakhogy ezeket egyetlen cikkből vettem! Viszont a következőkkel akkor is bajom lenne, ha egyenként találkoznék velük (de szintén csoportosan szerepeltek, ugyanabban a tanulmányban, mint az előbbiek): aktáns, cultural studies, diskurzus, diszkurzív, episztemikus, episztemológia, gender studies, genealógiai, hermeneutikai, heterotópia, ikonográfiai, kompartmentalizáció, kontextualizál, performatív, poszthumán, prezentizmus, science studies, szituált racionalitás, szociálkonstruktivizmus, transzláció. (...) Látszólag magyarok a következő szavak és kifejezések, amelyeket sutának mondanék, néha pedig egyszerủen nem létezőnek: beágyazatlanság, devizakitettség, feladatellátási hely (mint iskola), gépkocsiüzemanyag-töltő állomás (mint benzinkút), hozzájuthatóság, nevesítés, szándékhiány erősítése, valószínűsíthetőleg." Szerencsére ez utóbbiak nem egy szerző billentyűzetén teremtek.

- A Tér és Társadalom cikkeiben gyakoriak a földrajzi nevek. Ezek helyesírása még a művelt, de a geográfia szempontjából laikus olvasó számára is szép feladat, a szakmabeliek számára pedig kötelesség. Gyakran eligazítanak a gondosan szerkesztett térképek, amelyeket mindig érdemes fellapozni, ha az ember kis földrajzi táj nevét akarja leírni. Nem kell-e egy hátság, egy patak vagy egy tó nevébe kötőjel? Újra kiadták A földrajzi nevek helyesírása című könyvet (Fábián, Földi, Hőnye 2010). ${ }^{8}$ Szerzők és szerkesztők gyakori dilemmája, hogyan írják a magyar régiók nevét. Nem 
véletlen, hogy ez a gyakori kérdések között szerepel az MTA Nyelvtudományi Intézetének honlapján. ${ }^{9}$ Idézem az intézet válaszát. „A hivatalos elnevezéseknek megfelelően a hét magyarországi régió nevének írásmódja - egyébként a megyék írásmódjához hasonlóan - a következő: Nyugat-Dunántúl régió, Közép-Dunántúl régió, Közép-Magyarország régió, ÉszakMagyarország régió, Észak-Alföld régió, Dél-Alföld régió, Dél-Dunántúl régió. (...) A mindennapi nyelvhasználatban, de talán még a hivatalos kommunikációs formákat is beleértve ebbe, egyre inkább az -i képzős változatok jelennek meg. Így pedig leírva - egyébként pl. a járások írásmódjához hasonlóan - Nyugat-dunántúli régió, Közép-dunántúli régió stb. lenne a helyes írásmód. Ez viszont nem azonos a hivatalos megnevezéssel." (http://www.nytud.hu/oszt/nyelvmuvelo/gyik/regiok_neve.html) Ahogy a közönségszolgálat nem döntött, én sem foglalok abban egyértelműen állást, hogy a hivatalos név győz-e majd a széles körben terjedővel szemben. De legalább rá akartam mutatni, hogy az ügy nem problémamentes. Egy-egy szakfolyóirat sokat tehet az egységes írásmódért.

- A körülményes, túlrészletező fogalmazásra nem mentség, hogy a tudományos gondolkodás gyakran összetett mondatokban nyilvánul meg. Fent említett cikkemben ezért is morogtam, imigyen. Grätzer József gyermekkönyvében $(1986,42$.) olvasható egy összetett mondat, amelynek csak az elejét idézem: „Valamint a kalucsnira tapadó agyag ölelő karjaiból kibontakozó kocsikerék csikorgása által megriasztott tanyai kuvaszkutya bundájába kapaszkodó kullancsbogár szemeiből kicsorduló könnycseppekben visszatükröződő régi rabló lovagvár fölvonóhídjából kiálló rozsdás vasszögek összetartják annak alkotórészeit, azonképpen tartson össze benneteket a barátság és a szeretet..." Gyerekkoromban tetszett, szerkesztőként fárasztott az ilyesmi. Például a következő valós mondat egy létező cikkből: „Amennyiben ez a munkaerő »eladható «, azaz ilyen képességekkel más régióban működő vállalatok számára is alkalmas lehet, úgy amennyiben azok rendelkezésre állását kedvezőbb feltételekkel tudja a vállalatok számára elérhetővé tenni, úgy komparatív előnyei megnőnek más régiókhoz képest - vagy nevezhetjük globális versenyképesség javulásának is; mondandóm szempontjából ez csak terminológiai különbség."10

- Vannak olyan szavaink, amelyek felbukkanásakor (amikor a szerzőnek az eszébe jutnak) élni kell a gyanúperrel, hogy ködösíteni fognak, egy alkalmasabb szó helyére akarnak befurakodni. Ilyen a „kapcsán”, a „nem igazán”, az „összefüggésben”, a „tekintetében”, a „vonatkozóan” s a többi. Például: „Mi történne, ha minden településről azonos számú embernek kellene a hivatalba utaznia, például egy önkormányzatokkal kapcsolatos ügyintézés kapcsán?” (idézi Marosi 2011) Kis javítással: „... ügyintézés céljából." Jelentősebb javítással: „Mi történne, ha minden településről ugyanannyi embernek kellene az önkormányzati hivatalba utaznia, hogy ügyeket intézzen?" 
- Az objektivitás nem követel személytelenséget. Helyénvalónak tartom, hogy az a kutató, aki döntően egyedül dolgozott, maga határozta meg módszerét, végezte az adatgyüjtés érdemi részét, szinte önállóan jutott következtetésekre, munkájáról egyes szám első személyben számoljon be. A többes szám első személy egyes iskolák elvárásának tett engedmény vagy tévesen értelmezett szerénység. Mindenesetre homályban tartja, hogy kiknek a nevében ír a szerző. (Szerzőtársak vagy kollektív kutatás esetén világos a helyzet, kell a többes szám.) Az egyes szám első személyben fogalmazó szerzőnek természetesen lehettek segítótársai, akiket illik említenie, s akiknek kifejezheti köszönetét. Az egyes szám első személyü cikkben lehetnek többes számban fogalmazott mondatok: akkor, ha a szerző az olvasókkal együtt lát be valamit, jut következtetésre.

- A hipotézisalkotás nem nyelvtani, nem stilisztikai feladat, hadd füzzek hozzá mégis megjegyzést! Akár szóba hozza a szerző, akár nem (ha doktori értekezésen dolgozik, akkor majdnem biztosan kitér rá), aki kutatásba fog, abban motoszkálnak előzetes feltételezések, nevezze ezeket bárminek. Ha elvárják tőle, hogy munkáját hipotézisek rendszerére építse, meg fogja tenni, még azon az áron is, hogy utólag, az eredmények ismeretében fogalmazza meg „tudományos” feltételezéseit. ${ }^{11}$

- A mondatokon belüli gyakori felsorolások sajátos egyeztetést igényelnek. Az egyes és többes számú névszók együttes jelenléte, olykor váltakozása megnehezíti az ige alakjának megválasztását. A probléma a különböző számosság elkerülésével vagy több ige bevonásával oldható meg, amely igék közül az egyik egyes számban, a másik többes számban szerepel. A tárgyas és tárgyatlan ragozás mondaton belüli keveredése is gyakori. Nemcsak fület sértő, hanem értelemzavaró is lehet. Több mondatra bontással, külön igék alkalmazásával küszöbölhetjük ki.

- A kötőszók a logikus gondolatmenet, a levezetés, a bizonyítás, a következtetés szerény, ám nélkülözhetetlen eszközei: ha-akkor, ${ }^{12}$ mind-mind, ${ }^{13}$ nemcsak-hanem is, ${ }^{14}$ hasonlóan-ellenkezőleg, de, tehát, következésképpen, és, vagy, és/vagy, illetve stb. Az „és”-nek és a „vagy”-nak általánosan ismert szerepe van a szimbolikus logikában. (A szerzőnknek legfeljebb a hozzájuk kapcsolódó vessző szükségességéről kell jól dönteniük.) Nekem az „és/vagy”-gyal, no meg az ,illetve” szóval van bajom. „És/vagy” a köznyelvben nincs, ezzel az öszvérrel a szakzsargonban, főleg írásban lehet találkozni. Használói - gondolom - azt akarják kifejezni, hogy az „és/vagy” által összefüzött dolgok lehetnek egyidejűleg érvényesek, de lehetnek egymás alternatívái is. Feltételezhetik és kizárhatják egymást. E tömörítés barátai mondják meg, mit jelent a / jel! Inkább „és”-t? Inkább „vagy”-ot? Netán „és/vagy”-ot? Az „illetve” kötőszóval meg akkor van gond, ha az „és” váltópárjaként használják. Az „illetve” (teljes nevén „illetőleg”) az „és”-sel nem azonos értékű. Még csak nem is egy erősebb „és”, amely az „és”-eket már tartalmazó tagmondatokat füzi össze. (E 
célra ott van a „valamint”, a „továbbá”, az „ezenkívül”.) A Magyar értelmező kéziszótár (Juhász et al. 1992) szerint az „illetőleg” első jelentése a „pontosabban mondva, helyesebben”. Második jelentése azt fejezi ki, hogy a közlés részlegesen másra és másra vonatkozik, például „ki-ki megkapta a fizetését, illetőleg a nyugdíját”. Harmadik jelentése arra utal, hogy az állítás a felsoroltak mindegyikére egyaránt vonatkozik, például „ez az igazgatónak, illetőleg helyettesének a dolga”. (Még itt hasonlít leginkább az „és/vagy”-ra.)

- A szakirodalomra való hivatkozások mértéktelenül el tudnak harapódzni a tudományos igényü szövegekben. A szerkesztőségek általában elvárják (a Tér és Társadalom is megköveteli), hogy az irodalomjegyzékbe csak olyan művek kerüljenek, amelyeket a szerző tényleg felhasznált, s amelyekre - mintegy bizonyítékul - a szövegben hivatkozott is. Olcsó megoldás azonban egyetlen összetett mondatba 6-8 hivatkozást belesüríteni, még ha tagmondatonként két, három vagy négy pár zárójel közé osztja is el ezeket a szerző. Az egymást érő hivatkozások nemcsak azért kellemetlenek, mert letapossák egymás sarkát, megtörik az olvasás lendületét, hanem azért is, mert (szinte) semmit nem mondanak az említett ${ }^{15}$ müvekről. Ezért azt a kompromisszumot ajánlom, hogy a föszövegben csak a legfontosabb előzményeket említsük, s azokat is úgy, hogy mindegyikről mondunk valami érdemlegeset, mindegyikhez viszonyulunk. A többi hivatkozás kerüljön inkább a jegyzetekbe!

\section{A folyamatos szövegtől eltérő elemek}

Az élőbeszédhez leginkább hasonló szerzői gondolatfolyamból három információhordozó tűnik ki szemlátomást: a felsorolás, a táblázat és az ábra. Ezek felépítése fokozott figyelmet igényel a szerzőtől. Ha hibásak, akkor az olvasószerkesztő gyakran csak a szerző bevonásával tud segíteni. Szerencsére a tipikus hibák szembeötlők, ezeket a gyakorlott szerkesztő első látásra észreveszi, mielőtt belemerülne a kézirat olvasásába. Nem elegendő azonban, ha az egyes felsorolások, táblázatok és ábrák logikusak, szemléletesek és esztétikusak, hanem összességükben mértéktartó mennyiségünek, arányos elhelyezkedésűnek és a tördelés során (újra)szerkeszthetőnek kell lenniük.

\section{Felsorolások}

A felsorolások egyszintü, egymás után következő tételei (egyetlen összetett mondat tagmondatai vagy önálló tőmondatok) új sorban, bajusszal vagy egyéb jellel kezdődnek. Kedvező esetben minden tétel hasonló jellegü, például azonos 
mondatrész vagy azonos jellegű teljes mondat. Ez a szerkezet jól átlátható, könnyen befogadható. A felsorolás előtt világossá kell tenni, hogy a tételek milyen szempontból tartoznak össze, s azt is, mi határozza meg a sorrendjüket. (Rangsor? Betürend?)

Egy felsoroláson belül a tételeknek egységesen kisbetűvel vagy nagybetűvel kell kezdődniük. Ha a tételek csak tagmondatok, akkor logikus a kisbetűs kezdés. Ilyenkor azonban az egyes tételeken belül új mondatok nem kezdődhetnek. Kijelentő mondatok felkiáltó vagy kérdő mondatokkal ne váltakozzanak!

A listák Wordben való szerkesztése a tapasztalt felhasználónak tág lehetöségeket kínál, a gyakorlatlan felhasználó fölött pedig a szoftver szinte uralkodik. A technikai szempontból rosszul beállított felsorolások a tördelőszerkesztőnek adnak pluszfeladatot. A szerzőnek érdemes kézbe vennie a Word kézikönyvét, amely a beállítási lehetőségek között eligazít (Bártfai 2010). Többszintű felsorolás készítéséhez (amely összetettebb, több szempontú logikai feladat) a Kezdölap szalagon lévő Többszintű lista gombra kattintsunk! A folyóiratcikk azonban nem PowerPoint-előadás, úgyhogy nem helyes a teljes értékű szöveget vázlatpontokkal helyettesíteni.

\section{Táblázatok}

A táblázatok a mennyiségi vagy minőségi információ helytakarékos közlésének kétdimenziós térbe rendezett eszközei. Általuk különböző módszerekkel (például belső szalagcímekkel vagy táblázatok egész sorával) harmadik, esetleg negyedik dimenzióba tartozó adatok is megjeleníthetők. Alapvető térelemük a cella, amely egy sor és egy oszlop kereszteződésénél található. A táblázat címéből, szövegkoszorújából (az oldal- és fejrovatból) és a hozzá tartozó megjegyzésekből precízen ki kell derülni az adatok tartalmának, érvényességi idejének és helyének, méghozzá a tanulmány olvasása nélkül is. A táblázatoknak meg kell állniuk a saját lábukon. Betűméretük lehet kisebb az alapszöveg betüméreténél, és betűtípusa is eltérhet, ha ez könnyebben olvashatóvá teszi. ${ }^{16}$ További mondandóm ezúttal csak a számokat közlő táblázatokra vonatkozik.

Alapszabály, hogy egy cella csak egy adatot tartalmazhat. Aki úgy érzi, hogy táblázatának celláiba törtvonallal elválasztva vagy zárójelbe téve további számot is írni kellene, az tervezze át, válassza több, viszonylag önálló részre a táblázatát! A mértékegységeknek sem a cellákban van a helyük, hanem a szövegkoszorúban. Eltérő mértékegységek vízszintes és függőleges érvénnyel a cellában egymást nem keresztezhetik. Ha a táblázat minden cellájában szereplő számnak ugyanaz a mértékegysége, akkor kiemelendő a táblázat fölé. Ha ez alól a táblázaton belül kivétel adódik, akkor a kakukktojás-mértékegységet külön megjegyzéssel lehet ellátni, közvetlenül a táblázat alatt. A logikusan felépített, tiszta táblázat ismérve, hogy Excelbe áttéve műveletek végezhetők a számokkal. Az oldalrovat olykor nómenklatúrákat vagy más felsorolásokat tartalmaz. Ezek lehetnek teljesek, nem 
teljesek, tartalmazhatnak részösszegeket, teljes összeget. Ezeket minden esetben jól meg kell különböztetni, az átfedéseket, félreértéseket el kell kerülni. Helytakarékosság végett a sok számjegyü értékeket egységesen ezerrel, millióval vagy milliárddal osztva érdemes kevesebb számjegyre redukálni.

A szerzők egy része olyan technikai-módszertani információkat közöl a főszöveget megszakító táblázatokban, amelyek nem tartoznak a gondolatmenet lényegéhez, s még a kutatás részleteit megismerni akaró vagy a számításokat megismételni kívánó szakemberek számára is csak mint melléklet érdekesek. Az ilyen táblázatoknak ott is a helye, a mellékletek között. Különösen akkor, ha a szövegkoszorúban a változók elnevezései értelmezhetetlenek az átlagolvasó számára, mivel a gépi számítások változtatás nélküli rövidítései.

\section{Ábrák}

A térképeket, kartogramokat, diagramokat, elvi sémákat sorolom ide. Közös jellemzőjük, hogy az információk, adatok egymáshoz való viszonyait, különösen arányait szinte egyetlen pillantással átláthatóvá teszik. Ha ugyanazokat az adatokat táblázatban mutatjuk be, nagyobb pontosságra törekedhetünk ugyan, újabb számításokat teszünk lehetővé, de olvasóink másképp érzékelik majd az azonosságokat, különbségeket, arányokat és tendenciákat, mint ha mindezt geometriai eszközökkel tennénk elébük. Táblázat és ábra tehát nem helyettesítője a másiknak, bár hely szükében a szerzők választani szoktak közöttük.

A térképeknek arányosaknak kell lenniük, a közismert formák torzulása különösen zavaró, nem publikálható.

Azon folyóiratokba, amelyek fekete-fehér nyomtatásban jelennek meg, kizárólag erre tervezett tónusozással, raszterezéssel kell az ábrákat beküldeni. Az átható, szépséges, egymástól jól elütő színek azonos sötétszürkeként jelenhetnek meg.

A diagramok típusai széles választékban állnak ugyan rendelkezésre, például az Excelben is, de egy tervezett funkcióra nem mindegyik alkalmas. Százalékos megoszlások bemutatására leginkább a kördiagram való. (De nem a torta, amely öncélú játék a látszólagos harmadik dimenzióval. Az ilyen típusú „háromdimenziós" grafikonok megnehezítik az értékek leolvasását.)

Az oszlopdiagramok skáláját az alapponttól kell bemutatni. Ha „hely hiányában" levágjuk az oszlopok alját, akkor már csak különbségeket képesek bemutatni, arányokat nem, tehát értelmük felét biztosan elveszítik, sőt ártanak, hamis benyomást keltenek.

Az ábrák feliratai ne legyenek óriásiak, vastagok, és főleg ne tartalmazzanak helyesírási hibát! (A rövid és hosszú kötőjelek egy kalap alá vétele, valamint birtokos szerkezetek elől a határozott névelők elmaradása is hiba, amit nem ment, hogy gyakori...) Amíg a folyamatos szövegben az ilyesmit az olvasószerkesztő könnyen kijavítja, addig az ábrához esetleg nem tud hozzányúlni. Ezért a szerzőnek az ábraszövegeket a legnagyobb gondossággal kell megírnia. 


\section{Palackposta, az iránytű után hajítva}

A kéziratok gondozásának utolsó szakasza a következő: miután az olvasószerkesztő javított, a tördelő tördelt, a nyomdába szánt pdf-állományt a szerzők visszakapják utolsó ellenőrzésre, azzal az instrukcióval, hogy csak hibát keressenek, de a cikküket már ne akarják kiegészíteni. Észrevételeiket hibajegyzék formájában küldjék meg a szerkesztőségnek. S ők megküldik. Néha felülbírálják egyes javításaimat. Olykor jogosan. Ha a hibák százszorosát szürtem is ki eredeti kéziratukból, ezt le kell nyelnem, hisz a cél az, hogy az utolsó bennmaradtat is megtalálja közülünk valaki, mielőtt az olvasó találná meg.

Egyes szerzői reklamációk azonban arról tanúskodnak, hogy írójuk nem nézett utána a vitatott szónak vagy szabálynak. Még ekkor se, amikor pedig már csak 1-2 dolgot kellett volna fellapoznia a szótárban. ${ }^{17}$ Egyértelmü esetben ragaszkodtam a magam változatához, máskor meg inkább engedtem. Az utolsó folyóiratszámok munkálatai során például többször is találkoztam egy jelenséggel, amelyet a szerzők másképp írtak, mint én szerettem volna. Hirtelenjében nem találtam döntőbírót (a Nyelvtudományi Intézet közönségszolgálata éppen nem fogadott hívásokat), így hát visszatettem a vesszőt oda, ahová a szerző akarta. Most azonban, e sorok írása közben elértem a közönségszolgálatot, s amit megtudtam, palackba zárom, a vízbe hajítom, hiszen a hajó már elment. Hátha egyszer megtalálja valaki - az se baj, ha nem az eredeti címzett.

A dilemma tehát ez: tegyünk-e vesszőt a következő típusú mondatba a határozatlan és a határozott névelő közé? „A televízió híradója egy, a Műcsarnokról szóló riport közben végig a Magyar Nemzeti Galéria épületét mutatta." A szerzők vesszőt tettek, én töröltem. A nyelvművelő szakember szerint a helyzet vitatható. Valójában egy vitán felül álló fordulatot rövidítenek ilyenkor. Ezt: ,... a Mücsarnokról szóló egyik riport közben..." Már nincs egymás mellett két névelő.

A hajó elment. Ha fedélzetén régimódinak találjátok az iránytümet, szerezzetek be helyette GPS-t! Jó utat!

\section{Jegyzetek}

1 A tapasztalat szó ismétlésének elkerülésére hirtelen nem jutott eszembe jó megoldás, így a Magyar szinonimaszótárhoz fordultam (O. Nagy, Ruzsiczky 1978). Pusztai Ferenc főszerkesztésével 2010-ben új szinonimaszótár jelent meg (Pusztai 2010). Újdonság - és az előbbiek jó kiegészítése - az ellentétszótár (Temesi 2012).

2 Kovács Tibor hiába remélte, hogy a kéziratokban kevés lesz a hiba, úgyhogy a továbbiakban nem kifogásolta a nagyszámú korrekciót. Hét évig dolgoztunk együtt a lapon, mellette váltam szerkesztővé. Munkájáról, stílusáról, éles szeméről utóbb beszámoltam a Területi Statisztikában (Marosi 2005a).

3 A KSH honlapján is visszakereshető (Marosi 2005b, 2008, 2011). Bár a két folyóirat jellege nem azonos, és a technikai-formai követelmények is különböznek itt-ott, a korábban leírtakat fenntartom. Igyekszem inkább kiegészíteni, mint ismételni azokat. 
Mint tíz hónapos unokám.

5 „...magában a kutatásban a kíváncsiságomat akartam kielégíteni (...) Szóval, a kíváncsiság az megmarad. Akiben elmúlik, az lehet, hogy sikeres robotosa volt tudományának, de nem volt igazán alkotó. Az ember alkotóereje a korral megkopik. Tehát az én koromban új fölfedezésre már nem jut az ember. Szakmája válogatja, hogy meddig jut; a fizikában és a matematikában, mondják, harmincéves koráig kreatív igazán. De a kíváncsiság, a megismerés egy ilyen roppant változó világban, az megmarad. Csak már nem én tárom fel a titkokat, hanem felkészítem a tanítványaimat, a kollégáimat, hogy alkossák meg a maguk világát.” (Marosi 2010,266.) Ezt a nyelvi jelenséget remekül leleplezi Szathmári István Stilisztikai lexikonja (2004). Ragos névszóból és mindenes igéből álló szókapcsolat ez a terpeszkedő, amelyben az igének érdemi szerepe nincs. Viszont személytelen és terjengős, használója pedig azt hiszi, hogy mondanivalója így nyomatékosabb.

7 Az alcímnek lehet más szerepe is, például az olvasó kíváncsiságának fokozása. De ez nem a tudományos cikkekre jellemző, hanem például az olyan esszére, amilyet Területi hiányleltár (Horror vacui) címmel a Területi Statisztikába írtam. Részben az is a nyelvhelyességért emelt szót, ezért itt nemcsak hivatkozni fogok rá, hanem néhány bekezdést át is veszek belőle (Marosi 2011).

8 „Az Akadémia helyesírási szabályzatának 11. kiadására épül, figyelembe véve az utóbbi évtizedekben megjelent térképeken és névgyüjteményekben található, eddig nem szabályozott földrajzinév-írási típusokat is (...) Gazdag a szabályokhoz tartozó példaanyag, és jelentős segítséget nyújt a használóknak a példák betürendes mutatója is..." (vö. Magyar Tudományos Akadémia 1984, 2000, 2009)

9 A közönségszolgálat közvetlen telefonszáma a honlapon nem szerepel. 06 (1) 322 8038-at célszerű tárcsázni keddtől csütörtökig. Az elektronikus postacím bizonytalan, az én levelem nem ért célba.

10 Ez a mondat a Grätzer-féle mondókán kívül még a Bikini dalszövegére is emlékeztet: „Vasárnap este buli lesz, ha eső nem lesz, ha lesz, nem lesz, ha nem lesz, lesz" (idézi Marosi 2011). PhD-disszertáció védésén jött szóba, hiányosság-e, hogy a jelölt a munkáját nem indította hipotézisekkel. Én úgy láttam, hogy voltak érdemi feltételezései, de ezeket eleinte nem, csak az értekezés végén nevezte hipotéziseknek, ami nem hiba, legfeljebb szokatlan. A vita után Nemes Nagy Józseffel állapítottuk meg, hogy az erőltetett „hipotézis” biztos jele, ha a végeredményt két tizedesjegy pontossággal magában foglalja. Ilyesmire nem szabad ösztönözni, és szerkesztőként se kell szó nélkül hagyni. (Lehet a hipotézisek kezelésének egy jelölési-fogalmazási problémája is. Amikor a szerző - bármilyen jól megválasztott - első hipotézisét H1nek nevezi, az olyan, mintha egy szülő első csemetéjét B1 - Baby No. 1 - néven íratná be az iskolába, vagy egy médiaguru az ismert rádióadó jól hangzó nevét MR1-re fontosítaná, vagy egy közlekedésszervező a Szentendrei-HÉV-et H5-nek titulálná.)

12 Van, aki az „amennyiben-úgy” szópárt használja, ráadásul nyakra-főre. Lebeszélném róla.

13 Van, aki az „úgy-mint” szópárt használja, ami olykor egyáltalán nem helyettesíti a „mind-mind"-et.

14 Van, aki ebben a viszonylatban szintén külön írja a „nem csak”-ot, de ez azoknak a helyesírási szótáraknak a hibája is, amelyek nem különböztetik meg világosan az egybe- és a különírás szituációját.

15 Ezt írják egyes szerzők így: meghivatkozott... (Engem mindig elborzasztott.)

16 Őszintén szólva, a Tér és Társadalom táblázatának betűi ennek a kritériumnak nem feleltek meg. Örömmel hallottam kollégáimtól, hogy változtatást terveznek.

17 Például az alábbiak valamelyikében: Bárányné Szabadkai, Mihalik 2002; Deme, Fábián, Tóth 2004; Laczkó, Mártonfi 2006. 


\section{Irodalom}

Bárányné Szabadkai É., Mihalik I. (szerk.) (2002): Közgazdasági helyesírási szótár. Szakszavak, kifejezések, szókapcsolatok és röviditések gyüjteménye. TINTA Könyvkiadó, Budapest

Bártfai B. (2010): Word 2010 zsebkönyv. BBS-INFO Kiadó, Budapest

Deme L., Fábián P., Tóth E. (szerk.) (2004): Magyar helyesírási szótár. A Magyar Tudományos Akadémia szabályai szerint. Akadémiai Kiadó, Budapest

Fábián P., Földi E., Hőnye E. (2010): A földrajzi nevek helyesírása. Akadémiai Kiadó, Budapest

Grätzer J. (1986): SICC. Szórakoztató időtöltések, cseles csalafintaságok. Móra Ferenc Könyvkiadó, Budapest

Juhász J., Szőke I., O. Nagy G., Kovalovszky M. (szerk.) (1992): Magyar értelmező kéziszótár. Akadémiai Kiadó, Budapest

Laczkó K., Mártonfi A. (szerk.) (2006): Helyesírás. Osiris Kiadó, Budapest

Magyar Tudományos Akadémia (1984, 2000, 2009): A magyar helyesírás szabályai. Tizenegyedik kiadás. Akadémiai Kiadó, Budapest

Marosi L. (2005a): A szóra bírt zöld golyóstoll. Kovács Tibor főszerkesztői széljegyzetei. Területi Statisztika, 4., 401-419.

Marosi L. (2005b): Szerzőinknek. A folyóiratba szánt kéziratok tartalmi és formai követelményei. Területi Statisztika, 1., 92-95.

Marosi L. (2008): Kinek emlékeztetőül, kinek újdonságként. Szempontok a kéziratok elkészítéséhez. Területi Statisztika, 3., 367-369.

Marosi L. (2010): Látogatás a tudomány fellegvárában, Enyedi György akadémikusnál. Területi Statisztika, 3., 255-267.

Marosi L. (2011): Területi hiányleltár (Horror vacui). Területi Statisztika, 6., 573-580.

O. Nagy G., Ruzsiczky É. (szerk.) (1978): Magyar szinonimaszótár, A-ZS. Akadémiai Kiadó, Budapest

Pusztai F. (föszerk.) (2010): Magyar szinonimaszótár (Második, átdolgozott kiadás). Akadémiai Kiadó, Budapest

Szathmári I. (2004): Stilisztikai lexikon. Stilisztikai fogalmak magyarázata szépirodalmi példákkal szemléltetve. TINTA Könyvkiadó, Budapest

Temesi V. (főszerk.) (2012): Magyar ellentétszótár. Ellentétes jelentésü szavak szótára. TINTA Könyvkiadó, Budapest

http://www.nytud.hu/oszt/nyelvmuvelo/gyik/regiok_neve.html 


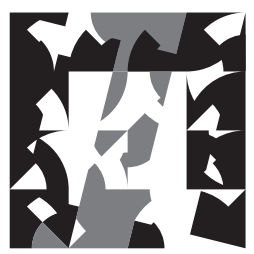

TÉR ÉS TÁRSADALOM | SPACE AND SOCIETY 